action of agents capable of reacting with cellular DNA. Recently the isolation ${ }^{3}$ of a DNA polymerase-deficient ( $p o l \mathrm{~A}^{-}$) strain has permitted the verification of this prediction. ${ }^{24}$ In the present study the sensitivity of such a mutant to gentian violet and related dyes was examined. TABLE.-Effect of agents on the growth of a
DNA polymerase-deficient strain of $E$. coli

\begin{tabular}{l|c|c}
\hline & \multicolumn{2}{|c}{$\begin{array}{c}\text { Diameter of zone of } \\
\text { inhibition (mm) }\end{array}$} \\
\hline \multicolumn{1}{c|}{ Agent } & Parent Strain & Mutant Strain \\
\hline Colistin (polymyxin F) & 14 & 14 \\
Kanamycin & 24 & 25 \\
Neomycin & 22 & 22 \\
Streptomycin & 19 & 19 \\
Ampicillin & 29 & 28 \\
\hline Methyl & 42 & 54 \\
N-Methanesulphonate & 4 & 44 \\
Nitrosi-N- & 3 & 44 \\
Nitrosofluorethe & 0 & 21 \\
\hline Gentian Violet & 8 & 21 \\
Crystal Violet & 11 & 20 \\
Methyl Violet & 7 & 10 \\
Malachite Green & 12 & 15 \\
Acridine Orange & 0 & 9 \\
\hline
\end{tabular}

The procedure used was essentially identical to the one described previously."

The data in the Table indicate that the parent and mutant strains exhibited equal sensitivities for a series of agents known not to react with cellular DNA - that is, ampicillin, kanamycin, streptomycin, neomycin, and polymyxin. On the other hand, as previously shown, ${ }^{4}$ the mutant strain was much more sensitive to the known carcinogens methyl methanesulphonate, nitrosomethylurethan, and nitrosofluorene, which react with cellular DNA. The mutant strain was also more sensitive than the parent to gentian violet, crystal violet, methyl violet, and malachite green.

The interaction between cellular DNA and the triphenylmethane dyes presumably is similar to the intercalative phenomenon which occurs when acridine dyes react with DNA. ${ }^{5}$ In the present context, it is perhaps significant that acridine orange, which also inhibits the pol $\mathrm{A}^{-}$strain preferentially (Table), has been reported to be carcinogenic for animals. ${ }^{6}$

As the experimental procedure used appears to be quite reliable in detecting mutagens and carcinogens ${ }^{4}$ and because agents first detected by this bioassay have been shown to induce tumours in animals (M. A. Anderson and H. S. Rosenkranz, unpublished results), the present findings suggest that the dyes listed above also react with the cellular DNA and might induce detrimental changes. Accordingly the continued clinical use of gentian violet and its congeners requires re-examination.

This study was supported by a grant from the Damon Runyon Memorial Fund for Cancer Research and by the Annie R. Masch Memorial Grant for Cancer Research from the American Cancer Society. H. S. R. is a Research Career Development Awardee of the National Institute of General Medical Sciences (2-K3-GM-29, 024).

-We are, etc.

HERBERT S. ROSENKRANZ HOWARD S. CARR

Department of Microbiology,
College of Physicians and Surgenns,

Columbia University,

New York, U.S.A.

1 Bielicky, T., and Novak, M., Archives of DermaBology, 1969, 100, 540 .
De Lucia, P., and Cairns, J., Nature, 1969, 224,

Kelly, R. B., Atkinson, M. R., Huberman, J. A., Slater, E. E., Ander Nature, 1969, 224, 495. A. H. S., Cancer Research, 1971, 31, 970. Lerman, L. S., Proceedings of the National Academy of Sciences of the U.S.A., 1963, 49, 94.

6 Van Duuren, B. L., Sivak, A., Katz, C., and Melchionne, S., British fournal of Cancer, 1969 ,
238.

\section{Chromosome Breakage and Ultrasound}

SIR,-Since publication of our preliminary communication "Chromosome Aberrations Induced by an Ultrasonic Fetal Pulse Detector" (10 October 1970, p. 92), there have been several communications describing similar work with negative results (Mr. W. T. Coakley and others ( 9 January, p. $109)$ and Dr. Elizabeth Boyd and others (29 May, p. 501)).

Some of my more recent work has suggested a possible reason for the discrepancy. My cells were treated in a vessel $1 \mathrm{~cm}$ in width and $4 \mathrm{~cm}$ long with polyethylene windows at either end. I have used Schlieren photography to examine the shape of the ultrasonic beam produced by the crystal of the Doptone probe, which I have used throughout. According to the manufacturers this beam is focused and my Schlieren photographs show that the beam from my crystal has a clearly defined focal point at a distance of $3 \mathrm{~cm}$ from the crystal. The beam is not affected by passage through the polyethylene windows, and the Figure is an attempt to show the distribution of ultrasound within the dimensions.

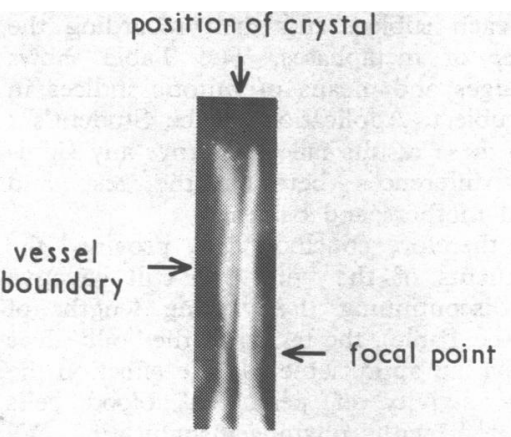

Main Ultrasound Beam within Vessel

It can be seen that the distribution of ultrasound is far from uniform, with the main beam having a width of only $3 \mathrm{~mm}$ at the focal point. This could lead to very high local intensities of ultrasound being delivered to some cells within the vessel.

It is unlikely that such high levels of ultrasound were possible in the apparatus described by Dr. Boyd and her colleagues.I am, etc.,

\section{J. C. Macintosh}

Department of Bio-engineering and Medical Physics, Medical School,

University of Cape Town,

S. Africa

\section{Care of Chronic Psychotics}

SIR,-We would like to comment on your leading article (15 May, p. 351) on "Care of Chronic Psychotics" in which the doubts cast on the future need for mental hospital beds and the effectiveness of community mental health programmes are discussed.

Our experience in Saskatchewan has ful- filled our initial high hopes. In 1962 Saskatchewan had the highest ratio of patients in mental institutions (per 100,000 population) in Canada, ${ }^{1}$ and one of the highest rates anywhere. A change in system was warranted and was brought about by a programme which envisaged comprehensive, regionalized psychiatric care with good follow-up and no buck-passing to remote mental hospitals. By gradual exploration, research, organizational changes, and planning, the success of this system has been achieved.?

Mental hospital population has fallen from 3,091 in 1962 to 882 by July 1971 (0.8 per 1,000 population).

It has been made possible to provide psychiatric care for all types of identified psychiatric problems arising in a definite area in an open unit attached to the regional hospital. A five-year review of such a centre has been published. ${ }^{3}$ In Prince Albert, total psychiatric care is catered for a population of 120,000 from a 60-bed general hospital psychiatric unit (0.5 per 1,000 population). Clinical areas are divided into six sub-areas. To each of these is allocated a psychiatrist, a psychiatric social worker, and a psychiatric community nurse, who form a treatment team. Each team is responsible for a population of about 20,000 and works directly with other facilities and agencies in their area. Outpatient clinics are held in the geographical areas and when patients are admitted from these areas they continue to be in contact with the same team personnel.

The inpatients' stay has averaged 21 days for 1970 in our unit. The re-admission rate has dropped dramatically except for chronic alcoholics and behaviour disorders. Patients are discharged directly into the community and no use is made of the halfway houses as they do carry the stigma of mental illness and foster dependency. Where family help is not available the patients are placed in approved homes. These homes are selected by the Department of Health or Welfare according to the physical and emotional environment of the family involved. The heads of these families attend orientation courses and thus are aware of mental illnesses and their handling in the community. These patients are visited regularly by community staff and day-to-day problems are dealt with while they are still in the community.-We are, etc.,

M. Z. Hussain A. G. KhaN

Department of Public Health,

Psychiatric Centre,

Province of Saskatchewan

Dominion Bureau of Statistics: Mental Health Statistics, 1962. Ottawa D.B.S. 1964.

Smith, C. M., Canadian Psychiatric Association

Fournal, 1971, 16, 65 .

1970, 127, 232., American fournal of Psychiatry,

\section{Levodopa and Anticholinergic Drugs} in Parkinsonism

SIR,-In attempting to explain the fact that patients suffering from Parkinson's disease are aided by anticholinergic drugs, Professor J. H. Burn (26 June, p. 773) draws an analogy between the central dopaminergic fibre and the peripheral adrenergic fibre. He has adduced evidence that in the latter noradrenaline is released through prior release of acetylcholine, and he now suggests that the same may pertain to the release of 
dopamine. In Parkinson's disease dopamine is deficient in the striatum but, according to Professor Burn, acetylcholine would be liberated from the nigrostriatal fibres and would produce symptoms of its own, unless checked by an anticholinergic agent or unless dopamine were made available by administration of levodopa.

This seems unlikely, for pathological evidence indicates that in Parkinson's disease it is not simply a biochemical function that is lost, but rather the entire fibre extending back to the substantia nigra. ${ }^{1-3}$ Degeneration of the nigrostriatal fibres with their entire neuronal complement of enzymes, substrates, and transmitters, is supported by much experimental evidence that has become available since $1964-65,3-6$ so that even if Professor Burn is correct in his hypothesis about the acetylcholine-catecholamine sequence of events in nerves, neuronal degeneration would result in the loss of the two functions at about the same rate and to the same extent.

Of course, there is considerable evidence for the cholinergic nature of many fibres of the corpus striatum, and it is readily conceivable that dopamine, released as a transmitter from specific neurones impinging upon these, would exercise a tonic inhibitory action. The same net result could be produced alternatively (or synergistically) by an anticholinergic drug acting at the terminations of the acetylcholine-producing fibre. Indeed, experimental evidence has recently been brought forward in favour of this and in relation to the action of levodopa, although other possibilities are not thereby excluded.

I hope that this will clarify an issue first raised by Dr. R. C. Hughes and his colleagues (29 May, p. 487).-I am, etc.,

THEODORE L. SOURKES

Departments of Psychiatry and Biochemistry,

McGill University,

1 Foix, C., and Nicolesco, J., Anatomie cérébrale les noyaux gris centraux et la région mésen céphalo-sous-optique, Paris, Masson et Cie, 1925.
. Adams, R., van Bogaert, L., and van der Ecken, H., Psychiatria et Neurologia, Basel, 1961, 142,

Poirier, L. J., and Sourkes, T. L., Brain, 1965, Poirier, L. J., Sourkes, T. L., Bouvier, G.,
Boucher, R. and Carabin, S., Brain, 1966, 89, 37.

Sourkes, T. L., and Poirier, L. J., Advances in Lancaster, G. K., Sourkes, T. L., and Poirier, L. J., Yournd of the Neurological Sciences, 1970, 11. 265. 7 Larochelle, L., Bédard, P., Poirier, L. J.; and 273.

\section{Accident and Emergency Services}

SIR,-Mr. A. M. Murray's comment on the treatment and disposal of injuries by general practitioners (28 August, p. 536) must not go unchallenged. Recent figures from another big casualty unit in central Glasgow, in which I hold a general practitioner appoint-

\section{Mitotic Indices and Oral Contraceptives}

SIR,-During the last year we have been investigating various aspects of oral contraceptives-for example, transformation of peripheral blood lymphocytes, chromosomes, sex chromatin, etc. We thought it might be of interest to make available our results relating to mitotic indices of peripheral blood leucocyte cultures of mothers who had taken various types of "pill," and their progeny, together with the time between stopping the "pill" and the onset of pregnancy.

Bloods (cord from the newborns and and peripheral venous from mothers) were collected at the time of delivery from mothers who had been on any form of oral contraceptives, their newborns, and from suitable controls. They were then coded and sent to the cytogenetic laboratory for culturing and harvesting by standard procedures previously described. ${ }^{1}$

Calculation of mitotic indices (percentage of mitoses) involved examination of 500 cells from each subject and then recording the number of metaphases. The Table shows the ranges and means of mitotic indices in each subject. Application of the Student's $t$ test to these results failed to prove any significant differences between the test and control mothers and babies.

We therefore conclude that, provided the constituents of the "pill" are still effective after discontinuing the varying lengths of time (see Table), the taking of the "pill" does not have an appreciable adverse effect on the mitotic activity of peripheral blood cells stimulated with phytohaemagglutinin.-We are, etc.,

\section{N. P. BishuN} J. MnLs

Research Department,

Marie Curie Memorial Foundation,

Oxted,

1 Bishun, N. P., Morton, W. R. M., and McLaverty, B., Lancet, 1964, 2, 315 . ment, show that only $4.6 \%$ of the total patients seen are non-emergencies referred by their family doctors.

Modern standards require that the majority of accidents should be treated with hospital facilities. As your leading article (14 August, p. 385) stated, "these cases often need careful treatment to avoid unnecessary delay in recovery and interference with employment"-aims which are the essence of good general practice.-I am, etc.,

Glasgow W.3

DONALD B. McFARLANE

\section{Treatment of Myocardial Infarction}

SIR,-Dr. H. G. Mather and others are to be congratulated on carrying out the careful trial of treatment of acute myocardial infarction (7 August, p. 334) comparing the mortality rates of those treated at home by the family doctor and those admitted to a hospital coronary care unit.

Their results suggest that, in general, by the time the general practitioner sees a patient with myocardial infarction at home it makes little difference, with regard to mortality, whether he is admitted to hospital or not. It has been shown by several groups of workers ${ }^{2}$ that the majority of deaths from this condition occur within four hours of the onset of symptoms and that the death rate falls off very rapidly after this period. The overall death rate, including sudden and early deaths, is around $40 \% . .^{12}$ The death rate among the patients of Dr. Mather and others was $15 \%$, indicating that most of the deaths had occurred before the general practitioners could get to the patients concerned. In order to have any chance of reducing the death rate from this condition to a substantial extent an organization is required which will make intensive coronary care available to patients within one or at most two hours of the onset of symptoms so that the dangerous bradycardia and arrhythmias that occur most often soon after the infarction can be corrected or cardiac resuscitation instituted if required. A mobile coronary unit summoned by the general practitioner before he goes to the patient or by the police, or even by the patient or a relative would appear to be one way of achieving this, in addition to encouraging members of the public to report acute chest pain to their doctor immediately.

Pantridge ${ }^{3}$ has shown that $27 \%$ of patients can be reached within an hour of onset of

\begin{tabular}{|c|c|c|c|c|c|c|c|c|}
\hline \multirow{2}{*}{ Pill } & \multirow{2}{*}{$\begin{array}{c}\text { No. of } \\
\text { Patients }\end{array}$} & \multicolumn{4}{|c|}{ Mothers } & \multicolumn{3}{|c|}{ Babies } \\
\hline & & Time* & Test & Control & Probability Values & Test & Control & Probability Values \\
\hline Ovulen-21 & 20 & $\begin{array}{l}0-60 \\
\text { Mean } 11 \cdot 4\end{array}$ & $\begin{array}{l}0-25 \% \\
\text { Mean } 4.7 \%\end{array}$ & $\begin{array}{l}0-10 \% \\
\text { Mean } 3 \cdot 2 \%\end{array}$ & $P>0.50$ & $\stackrel{0-28 \%}{\text { Mean }} 13 \cdot 1 \%$ & $\stackrel{0-26 \%}{\text { Mean } 9.7 \%}$ & $P>0.50$ \\
\hline Anovlar-21 & 8 & $\begin{array}{l}0-60 \\
\text { Mean } 17 \cdot 0\end{array}$ & $\begin{array}{l}0-28 \% \\
\text { Mean } 3.6 \%\end{array}$ & $\begin{array}{l}0-12 \% \\
\text { Mean } 4 \cdot 2 \%\end{array}$ & $P>0.50$ & $\begin{array}{l}0-28 \% \\
\text { Mean } 7 \cdot 2 \%\end{array}$ & $\stackrel{0-22 \%}{\text { Mean } 10.6 \%}$ & $0.50<P>0.10$ \\
\hline Gynovlar-21 . & 11 & $\stackrel{0-36}{\text { Mean 6.3 }}$ & $\begin{array}{l}0-28 \% \\
\text { Mean } 10 \%\end{array}$ & $\begin{array}{l}0-25 \% \\
\text { Mean } 9.9 \%\end{array}$ & $P>0.50$ & $\begin{array}{l}1-28 \% \\
\text { Mean } 17 \cdot 3 \%\end{array}$ & $\begin{array}{l}0-28 \% \\
\text { Mean } 14.2 \%\end{array}$ & $0.50<P>0.10$ \\
\hline Norinyl-1 & 10 & $\begin{array}{l}0-18 \\
\text { Mean 4.5 }\end{array}$ & $\begin{array}{l}\text { O-20\% } \\
\text { Mean } 6.0 \%\end{array}$ & $\begin{array}{l}0-15 \% \\
\text { Mean } 4.6 \%\end{array}$ & $P>0.50$ & $\begin{array}{l}0-25 \% \\
\text { Mean } 11 \cdot 3 \%\end{array}$ & $\begin{array}{l}0-25 \% \\
\text { Mean } 6.8 \%\end{array}$ & $0.50<P>0.10$ \\
\hline Conovid-E & 7 & $\begin{array}{l}0-48 \\
\text { Mean } 11 \cdot 7\end{array}$ & $\begin{array}{l}0-25 \% \\
\text { Mean } 5 \cdot 7 \%\end{array}$ & $\stackrel{0-4 \%}{\text { Mean } 1.1 \%}$ & $0.50<P>0.10$ & $\begin{array}{l}0-28 \% \\
\text { Mean } 14 \cdot 4 \%\end{array}$ & $\begin{array}{l}0-15 \% \\
\text { Mean } 5.0 \%\end{array}$ & $P=0.05$ \\
\hline Lyndiol-1 & 7 & $\begin{array}{l}0-34 \\
\text { Mean } 11 \cdot 8 \\
\end{array}$ & $\begin{array}{l}0-20 \% \\
\text { Mean } 8 \%\end{array}$ & $\begin{array}{l}0-26 \% \\
\text { Mean } 9.5 \%\end{array}$ & $P>0.50$ & $\begin{array}{l}0-28 \% \\
\text { Mean } 10.8 \%\end{array}$ & $\begin{array}{l}0-28 \% \\
\text { Mean } 17.9 \%\end{array}$ & $0.50<P>0.10$ \\
\hline Minovlar-21 . & 7 & $\begin{array}{l}0-48 \\
\text { Mean } 9.8\end{array}$ & $\begin{array}{l}0-28 \% \\
\text { Mean } 9.8 \%\end{array}$ & $\begin{array}{l}\text { O-22\% } \\
\text { Mean } 6.2 \%\end{array}$ & $P=0.50$ & $\stackrel{0-28 \%}{\text { Mean } 11.2 \%}$ & $\begin{array}{l}8-25 \% \\
\text { Mean } 17 \cdot 0 \%\end{array}$ & $0.50<P>0.10$ \\
\hline
\end{tabular}

- Time in months between discontinuation of the pill and pregnancy. 